\title{
Silence in Argumentative Practices as a Manifestation of Tolerance
}

\section{Olena Shcherbyna}

\author{
Doctor of Philosophical Sciences, Associate Professor, Taras Shevchenko National University \\ of Kyiv (Kyiv, Ukraine) \\ E-mail: eyshcherbina@gmail.com \\ https://orcid.org/0000-0003-2931-7530
}

\section{Liudmyla Shashkova}

\author{
Doctor of Philosophical Sciences, Professor, Taras Shevchenko National University of Kyiv \\ (Kyiv, Ukraine) \\ E-mail: profshashkova@gmail.com \\ https://orcid.org/0000-0002-2054-0405
}

\begin{abstract}
The argument of silence as a manifestation of tolerance in the context of the problem of "familiarity and otherness" is represented in the article. The emphasis is put on future of empirical studies of argumentation. The informative, volitional and metallurgical functions of the argument of silence are shown through the examples of the group silence, namely the silence of the group of people present during the marriage ceremony in Christian and Muslim traditions. The differences in the role played by the argument of silence as a manifestation of tolerance in these traditions are defined. It is revealed that the distinguishing feature of the expression of the argument of silence in legal argumentative practices is the lack of measurable group tolerance since legal liability is always held by every individual as a subject of the delict. Here, the silence acts as a manifestation of tolerance as an agreement, acceptance, and protection of the point of view of another as one's own. The article emphasizes the importance of the further improvement of the methodology of social groups argumentation, as well as the development of methods for determining group arguments as a type.
\end{abstract}

Keywords: silence as an argument, functions of silence, tolerance, group tolerance, argumentative practices, legal argumentation

Received: September 12, 2019; accepted: September 30, 2019

Future Human Image, Volume 12, 2019: 76-84.

https://doi.org/10.29202/fhi/12/6

(C) Shcherbyna, Olena, 2019

(C) Shashkova, Liudmyla, 2019 


\section{Introduction}

The processes of integration and globalization give rise to the problem of preserving national cultures and traditions, that actualizes the necessity of the existence of the "familiarity and otherness" opposition. Since identifying the features of the "familiarity and otherness" opposition is impossible outside the context of tolerance, investigating named opposition in this aspect is quite promising.

There is a large number of papers on research on the issue of tolerance. The lack of general methodological guidance makes it difficult to understand tolerance as a social phenomenon. Scientists are discussing the concept of tolerance, its limits, the areas of its competence. For example, Vladislav Lektorsky distinguishes the following understanding of tolerance: 1) tolerance as indifference, which is associated with the classical liberal tradition. According to this understanding, the criticality of the existence of different views and practices is leveled out in the face of the main problems that society is facing; 2) tolerance as the impossibility of mutual understanding; 3 ) tolerance as a compassion for the weaknesses of others, which allows a degree of contempt for them; 4) Tolerance, which carries the potential for expanding one's own experience and involves a critical dialogue [Lektorsky, 1997: 15]. Vera Samokhvalova, in turn, focuses on the difficulties of understanding the phenomenon of tolerance, based on the extreme ambiguity of the meaning of this concept. "Often, the establishment of this concept is dictated not so much by some kind of a semantic necessity ... but as a retaining inherent in our time of the spirit of non-differentiation, confusion, indifference, that is, tolerance to the meaning of the expression. In this case, the use of this concept often does not clarify, but confuses, confuses, makes the situation incomprehensible" [Samokhvalova, 2008: 161-165]. Abdusalam Guseynov, referring to tolerance as a universal principle of behavior, draws attention to the fact that if one understands tolerance as a requirement not to impose on to another one's own views that are unacceptable to him, then uncertainty disappears [Guseynov, 2008: 34-43]. Emphasizing that there is no unambiguous understanding of the category of "tolerance" and the limits of its application in the comprehension of modern post-industrial reality, Alexander Khyzhniak stresses that this "complicates the formation of tolerance as a condition of human existence and vital activity in a multicultural environment" [Khyzhniak, 2014: 34-43].

In the article by Rainer Forst "Tolerance" in the Stanford Encyclopedia of Philosophy, four conceptions of tolerance are considered. According to the first conception that the author calls the concept of permission, tolerance is the relationship between the authorities or the majority and disagree or the "other" minority (or different minorities). In this case, tolerance means that the government gives a qualified permit to the minority to live in accordance with their beliefs, provided that the minority recognizes the dominant position of the authorities or the majority. The second concept, the concept of coexistence, is similar to the first one, dealing with tolerance as the best means of stopping or avoiding conflict and achieving its own goals. However, the attitude of tolerance is more horizontal than vertical: the subjects are at the same time the objects of tolerance. In contrast to the two previous ones, the third concept of tolerance is the respect conception, the one in which the toleration parties respect each other in a more reciprocal sense. Two models of "concept of respect" are distinguished: "formal equality" and "qualitative equality". The first is based on a clear distinction between the political and private spheres, according to which the ethical (ie cultural or religious) differences between citizens of the legal state should be confined to the private sphere to prevent conflicts in the political sphere. The model of "qualitative equality" recognizes that certain forms of formal equality use those 
ethical and cultural forms of life, beliefs, and applying which facilitate the traditional public / private distinction. According to this model, people respect each other as politically equal with a certain ethical and cultural identity that needs respect and tolerance as something (a) which is especially important for a person; and (b) can provide compelling reasons for certain exceptions to the general changes in existing legal and social structures. Consequently, social and political equality and integration are compatible with cultural differences - within certain (moral) limits of reciprocity. The fourth concept of tolerance the author of the article calls the esteem conception. It implies an even more demanding concept of mutual recognition of citizens than the respect conception. Here, to be tolerant, means not only to respect members of other cultural forms of life or religions as morally and politically equal, it also means certain ethical esteem of their convictions, that is to consider them ethically valuable representations, which even though they are different from our own are to some extent ethically attractive and supported by important reasons [Forst, 2007/2017].

The archetype "familiarity and otherness" ("friend-foe") does not lose its significance since the tribal system. This opposition appears in a variety of forms of expression, ranging from the very first forms of social organization (tribe) to globalization societies and local cultural groups. That is why the phenomenon of tolerance, as acceptance or leniency for another, is inextricably linked with the opposition "familiarity and otherness". Having considered any social group in terms of familiarity and otherness, we will see how tolerance manifests itself in modern society. The issue of group tolerance is fairly flexible for the research from the cultural point of view, but the legal aspect of tolerance is much more complicated since the law requires us to clearly define the role of each subject of legal action. That is why the analysis of group tolerance as a legal phenomenon is quite problematic. It is almost impossible to clearly define the role of each group member in practice, especially taking into account the difficulty of obtaining testimony from members of the group. In some cases, the legislation provides regulations for acting for law enforcers. For example, a law can not force a wife (husband) to testify against her husband (wife). Thus, the first part of Article 63 of the Constitution of Ukraine provides that "a person shall not bear responsibility for refusing to testify or to provide explanations about himself/ herself, members of his/her family, or close relatives, the circle of whom is determined by law" [The Constitution of Ukraine, 2019]. Here we see the permission for silence. Another thing is a group of people who are not legally assigned as a group. In this case, the law can force each member to testify against others, but even in this case the responsibility will be borne by a person individually, but not by a group as a unit of social action. These examples show the specific role of silence in the argumentative schemes of reasoning of groups as social units.

The purpose of this article is to represent the argument of silence as a manifestation of tolerance in the context of the problem of "familiarity and otherness" by putting emphasis on improving the methodology of argumentation of social groups in future empirical and theoretical studies of argumentation.

\section{The phenomenon of silence in contemporary argumentative studies}

Modern scientific literature examines the phenomenon of silence in its various aspects. Communicative function of silence has been a subject of increased scientific interest among researchers starting from the end of the twentieth century. Silence is being discussed "... only on the background of communication, that is, when, in principle, linguistic communication is possible - real or virtual" [Arutyunova, 1994: 109]. One of the earliest comprehensions of 
silence as a cultural phenomenon is found in the works of philosophers of Ancient Greece, who spoke about the connection between the thinking process and silence and the role of speech (speaking) in the cognitive process. In ancient schools (Pythagoreans, Orphics, followers of Taoism, Buddhists), silence acquires the status of the path to truth. Correlation of silence and the word as equivalent in the spiritual experience is encountered in Christian culture. In modern philosophy, silence is analyzed from the standpoint of philosophical hermeneutics as a discursive practice and way of linguistic behavior, grammar and semiotics of silence are studied from the standpoint of the pragmatic philosophy, silence manifestation in the language contexts and biblical, literary texts are investigated, and the ontological status of silence is considered.

In modern epistemic practices, the argumentation of tolerance is caused by situations of agreement/disagreement in which the impossibility of achieving an "aggregated" proposition raises the question: Can the epistemically equal individuals rationally disagree; Can they support their own opinion, although they assume that the other side may also be right? "Equal disagreement" is a situation that begins with an independently evaluated fact by different people [Elga, 2006]. An epistemically equal researcher is equal to an agent that investigates in parallel, but their final results are different. Standing on your own or giving your own result higher value is a dilemma that can be solved in two ways: equal weight and extra weight. "Equal weight" means the same value of one's own evaluation and epistemically-equal ones in the sense that everyone can claim to be correct. "Extra weight" means giving your own assessment a greater value than an assessment of the epistemically equal ones. At the same time, you can heed the guideline of equal, but consider yourself to be right. That is, "epistemically correct" considers itself to be equal, and "epistemically equal" considers everyone to be equal regardless of the accuracy and authorship of the assessment [Elga, 2006]. Consequently, "equal weight" applies to cases of disagreement, which can be manifested by silence. The so-called "discursive dilemma", that Adam Elga describes, reflects the aspect that the aggregative procedure under the majority vote does not provide consistent collective judgment, even with a sequence of individual judgments.

Communicatively meaningful silence of those who speak has frequently been the subject of studies of linguists, psychologists, philosophers, argumentation theorists. This question was considered in the writings of Nina Arutyunova [Arutyunova, 1994]; Michal Ephratt [Ephratt, 2008]; Tatiana Kopylova [Kopylova, 2015]; Anna Kretova [Kretova, 2018]; Grigoriy Kreydlin [Kreydlin, 2004]; Georgiy Pocheptsov [Pocheptsov, 1986]; Muriel Saville-Troike [SavilleTroike, 1985]; Yan Zuo [Zuo, 2002] etc. Silence as an argument was investigated by John Lange [Lange, 1966]; Douglas Walton [Walton, 1999]; Christopher Stephens [Stephens, 2011]; Mike Duncan [Duncan, 2012]; Timothy McGrew [McGrew, 2014]; Haig Khatchadourian [Khatchadourian, 2015]; Zachary Milstead [Milstead, 2018] etc.

A weak argument in argumentation is an argument in which its premise provides poor support for the conclusion. Such a premise is not strong enough in order to persuade the other party (participant of the dispute) in the reasonableness of the conclusion in the process of an argumentative dispute. In argumentative practices, the argument of silence is usually considered as a weak argument. However, while analyzing the problem of bad and good arguments, researchers, who work in the sphere of logic and argumentative theory are trying to set the difference between the so-called good argument from silence and a bad one. Based on the fact that even good arguments from silence are always weak, unconvincing, there is a widespread view that the best thing that an argument from silence can provide on its own is indirect evidence. Like an appeal to authority, the strength of an argument from silence depends to a large extent on the power of authority in a particular matter and, in particular, what we can expect from this 
authority. In the context of appealing to authority, the question of acknowledging authority is a topical issue, especially when we fall into the field of the opposition "familiarity and otherness".

One of the characteristic features of the argumentative function of silence in argumentation, in particular legal, is that during its execution, it simultaneously implements its other functions: informative, volitional and metalinguistic. In the center of the volitional function presents a second person: The Other ("You"). Within this function, eloquent silence is aimed at activating the addressee (suspected, accused, witness) to defense from the presentation of disadvantageous accusations, that is, silence as a defense against self-incrimination. Speech (or silence) here does not serve for (true or false) statement (about the outside world - a third person), but itself is a linguistic act.

The metalinguistic function that uses language not as a tool but as a research goal, with regard to silence, is a controversial issue. Scientists dispute about whether silence can be used to comment or express the question of the structure of the language itself. Michal Ephratt showed the role of eloquent silence as an indication of a turning point in a dialogue that defines silence as a marker of discourse, which plays a metalinguistic role in conducting a dialogue, thus activating the interlocutor (volitional function) [Ephratt, 2008].

\section{The role of silence as a manifestation of tolerance in the argumentative practices of social groups}

Group silence can be considered as an example of informative, volitional, and metalinguistic functions of silence in argumentative practices: the silence of the group of present during the marriage ceremony in the Christian tradition (here, silence acts as a manifestation of tolerance as leniency and condescension to the choice of another that is close to "qualitative equality" - one of the models of the concept of respect), the Muslim tradition (silence here can be interpreted as a negative response, taking into account the context in which the present understand that there is a need in response, that is, it is a metalinguistic function of silence) and specificity in the legal context of the argument of silence as a group tolerance of the religious group members (here silence acts as a tolerance manifestation as agreement, acceptance and protection of the other's point of view as our own). According to the Christian tradition, the host of the marriage ceremony is obligated to ask all those present whether they have something against this marriage. It is usually expressed as follows: "If anyone knows why the couple should not be joined in holy matrimony, let them speak now or forever hold their peace". This tradition dates back to the 16th century, namely the "The Book of Common Prayer", which was first concluded in 1549, during the British Reformation. The book contained following lines: "Therefore if any man can show any just cause why they may not lawfully be joined so together: Let him now speak, or else hereafter forever hold his peace" [The Book of Common Prayer, 1549]. The same lines are present in the current version of the book [The (Online) Book of Common Prayer]. The very phenomenon of the requirement to certify the legitimacy of the marriage by the present people comes from the prohibition of secret marriages, that is, marrying during which witnesses were absent. Such prohibition is also expressed in the texts of The Canons of the Fourth Lateran Council in 1215: "Clandestine marriages and witness to them by a priest are forbidden. Marriages to be contracted must be published in the churches by the priests so that, if legitimate impediments exist, they may be made known. If doubt exists, let the contemplated marriage be forbidden till the matter is cleared up" [The Canons of the Fourth Lateran Council, 1215]. This prohibition is linked to the prohibition of marriage between direct relatives as well as to polygyny. In this context, 
we emphasize that the specified cultural tradition (marriage), which has religious origins, has received its legal reinforcement, which also exists in the modern world. For example, according to the Article 39 "Invalid Marriage" of the Family Code of Ukraine, a marriage registered with already married person whose first marriage has been registered is deemed to be invalid, as well as a marriage registered between persons that are relatives related to one another by blood, as well as between full blood brother and sister is deemed to be invalid. Even greater connection with the provisions of the Canons of the Fourth Lateran Council of 1215 is found in part four of the same article 39 of the Family Code of Ukraine, which states that "the public civil status act registration authority, upon application of the person concerned, cancels the record of marriage registered with persons referred to in paragraphs $1-3$ of the present Article" [The Family Code of Ukraine, 2018]. Thus, the act of silence as a form of manifestation of tolerance indicates the connection between the religious and legal component of marriage.

According to the Islamic tradition, the witnesses and parents should be present at the nikah reading. Without witnesses who would certify their consent to the union, marriage can be considered as invalid. Traditions of reading nikah differ in different regions, but many sources argue that during nikah the couple, all witnesses and parents (or guardians) are asked about whether they understand and remember what is happening and whether they give their consent to this marriage. According to this, we can assume that the silence of any of those who have been asked may be regarded as a negative response (negative non-speaking). It is worth paying attention that in many Muslim countries there are no separate state bodies that register a marriage, and therefore the certificate provided by the mosque (as an institution) is recognized by the state. Consequently, this can be considered as an example of both religious and civil marriage (legally recognized), in which silence performing its argumentative function can simultaneously perform informative, volitional and metalinguistic functions.

If a group is religious and is not legally prohibited, then according to the law a person who is a member of this group is obligated to testify during the inquiry, pre-trial investigation or trial in respect of other members of a group in case of committing criminal acts. In accordance with Part 2 of Article 385 of the Criminal Code of Ukraine, a person "who refuses to testify against himself/herself, members of his/her family or close relatives whose circle is stipulated by law, during an inquiry, pretrial investigation or in court, shall not be criminally liable" [The Criminal Code of Ukraine, 2019]. From a legal point of view, in this case, we can talk about the lack of measurable group tolerance, since in that case responsibility will be borne by each person individually as the subject of the offense and not by the group, taking into account that membership in an organized criminal group can act as an aggravating circumstance. After all, illegal activity in the realm of religious life may have different manifestations and be associated with common criminal offenses, which in Ukrainian legislation is regarded as a violation of the norms of criminal law and is punishable according to the Criminal Code of Ukraine, depending on the qualifying features of the crime.

As author has noted in previous writings before ${ }^{1}$, performing the volitional function in legal argument, silence can be a means of implementing an agreement ("silence as a confession of guilt", "silence as a way of expression of will" in relation to cases when it has the law-making power), can act as a defense against self-accusation, as well as a method of deception. In the latter case, the deception through the keeping silent about a part of legally meaningful information and the tacit deception of one of the communicants may carry information about the unlawful encroachment on the will of another. Cautions in the act of warning about the right to remain

\footnotetext{
${ }^{1}$ See [Shcherbyna, 2014; 2015].
} 
silent (for example, the "Miranda Rule") use words which content falls under the metalinguistic function. It is about the possible consequences of speaking and possible interpretations of the right to remain silent. By performing an argumentative function in legal argumentation, silence can be represented both as a reception of influence in a dispute and as an argument (it refers to arguments ad rem). As the reception of influence in the dispute silence in legal argumentation can be both "silence of restraint" (e.g. one of the parties in the process of litigation) and "silence of courage" (e.g. refuse to testify in order not to frame someone other). Silence as an argument on the merits of the case in legal argumentation acts as a prohibition on communication, defined by international norms.

The right to keep silence has ambiguous interpretation for the cases where silence is used as an argument by one member of a group to protect its other members. This is especially relevant for religious groups, because we can not be sure what exactly in this context silence is (the will of one person or one of the necessary conditions for belonging to a particular religious group). Proceeding from the fact that modern tendencies of social relations show increased attention to the role of tolerance in society, we believe that in future investigations of the argumentation processes the study of the argument of silence will open new perspectives in the understanding of tolerance.

\section{Conclusions}

Consequently, in our opinion, everything analyzed above represents the argument of silence as a manifestation of tolerance in the context of the problem of "familiarity and otherness". Demonstrating the informative, volitional and metalinguistic functions of silence, on examples of group silence, namely the silence of the group of present people during the marriage ceremony in Christian and Muslim traditions, the differences between the roles played by the argument of silence as a manifestation of tolerance in these traditions were set. The emphasis is placed on the fact that silence acts as a manifestation of tolerance as indulgence and leniency to the choice of another person in the Christian marriage ceremony, which is close to one of the models of the concept of respect — "qualitative equality". In the Muslim marriage tradition, silence can be interpreted as a negative response, taking into account the context in which the present people realize that there is a need for an answer.

Presented in this article examples demonstrate the specific role of silence in the argumentative schemes of reasonings of groups as social units. The peculiarity of the manifestation of the argument of silence in legal argumentative practices is the lack of measurable group tolerance, since in that case responsibility will be borne by each person individually as the subject of the offense and not by the group (in particular, the religious organization), taking into account that membership in an organized criminal group can act as an aggravating circumstance. Here, silence acts as a manifestation of tolerance as an agreement, acceptance, and protection of the point of view of another as our own.

Since the argument of silence, by acting as a manifestation of tolerance, fulfills its communicative, argumentative, informative, volitional, and metalinguistic functions, we believe that in future empirical and theoretical studies of the process of argumentation, this topic will get its further implementation. It is about improving the methodology of argumentation of social groups, as well as developing ways to define group arguments as a type. A further perspective of research of theorists of argumentation can be the following questions: what is the difference between the individual arguments and the group arguments? At what point of 
argumentation analysis, we can assume that we are dealing with precisely group arguments? Which argumentation agents can the "matrix" of group arguments be applied to? The above will give an opportunity to study the dynamics of the manifestation of tolerance in the prospects of the development of research on silence as an argument.

\section{References}

Arutyunova, Nina. "Word of Silence": Extension and Distribution. Logical Analysis of Language. The Language of Speech Acts. M., 1994: 106-117 (in Russian).

Duncan, Mike. The Curious Silence of the Dog and Paul of Tarsus: Revisiting The Argument from Silence. Informal Logic, Vol. 32, No.1, 2012: 83-97.

Elga, Adam. Reflection and Disagreement. NOUS. Aug., 2006: 478-502.

Ephratt, Michal. The functions of silence. Journal of Pragmatics. V. 40 (11), 2008: 1909-1938.

Forst, Rainer. Toleration. Stanford Encyclopedia of Philosophy. First published Fri Feb 23, 2007, substantive revision Wed Jul 12, 2017: https://plato.stanford.edu/entries/toleration/

Guseynov, Abdusalam. What We Speak about when we speak about the Dialogue of Civilizations.

The International Affairs, 3, 2008: 34-43 (in Russian).

Khatchadourian, Haig. How to Do Things with Silence, xiv, 2015.

Khyzhniak, Alexander. Labyrinths of tolerance. Kharkiv: V. N. Karazin Kharkiv National University, 2014.

Kopylova, Tatiana. Silence as a term: the problem of polysemy. Bulletin of Udmurt University. Series History and Philology. Vol. 25, Issue 5, 2015: 7-11(in Russian).

Kretova, Anna. Borders of Silence in Communication. Philological Sciences. Issues of Theory and Practice. Tambov: Gramota, 12 (90). Part 3, 2018: 547-550 (in Russian).

Kreydlin, Grigoriy. Nonverbal semiotics. Body language and natural language. Moscow, 2004 (in Russian).

Lange, John. The Argument from Silence. History and Theory, Vol. 5, No. 3, 1966: 288-301.

Lektorsky, Vladislav. On tolerance. Philosophical Sciences, 3-4, 1997: 14-18 (in Russian).

McGrew, Timothy. The Argument from Silence. Acta Analytica, 29 (2), 2014: 215-228.

Milstead, Zachary. Religion and Arguments from Silence. European Journal for Philosophy of Religion, 10 (3), 2018: 155.

Pocheptsov, Georgiy. Silence as a sign. Analysis of the sign systems: History of Logic and Methodology of Science. Kiev, 1986: 90-98.

Samokhvalova, Vera. The Notion of Tolerance in the Context of Modern Culture. Philosophical journal, 1, 2008: 161-165 (in Russian).

Savill-Troike, Muriel. The place of Silence in an Integrated Theory of Communication. Perspectives on Silence. Ed. By D.Tannen, M. Savill-Troike. Univ. of Illinois, 1985: 31-54.

Shcherbyna, Olena. Phenomenon of Silence in Legal Argumentation. Philosophy of Law and General Theory of Law. Academic journal. Ed. journal "Law of Ukraine", 1-2, 2014: 160-174.

Shcherbyna, Olena. The relationship of volitional, metalinguistic and argumentative functions of silence in legal argumentation. European Political and Law Discourse. V. 2, Iss. 5, 2015: 54-59.

Stephens, Christopher Lee. A Bayesian Approach to Absent Evidence Reasoning. Informal Logic, 31(1), 2011: 56-65. 
The Book of Common Prayer, 1549. http:/justus.anglican.org/resources/bcp/1549/ Marriage_1549.htm

The (Online) Book of Common Prayer. https://www.bcponline.org

The Canons of the Fourth Lateran Council, 1215. https://sourcebooks.fordham.edu/basis/ lateran4.asp

The Constitution of Ukraine. Document 254k/96-BP, valid, current version - Revision on February 21, 2019, on the basis - 2680-VIII. https://zakon.rada.gov.ua/laws/ show/254к/96-вp?lang=en

The Criminal Code of Ukraine. Document 2341-III, valid, current version - Revision on October 18, 2019, on the basis - 140-IX. https://zakon3.rada.gov.ua/laws/show/234114/page 13?lang=en

The Family Code of Ukraine. Document 2947-III, valid, current version — Revision on August 28, 2018, on the basis - 2475-VIII. https://zakon3.rada.gov.ua/laws/show/294714? lang=en

Walton, Douglas. The Appeal to Ignorance, or Argumentum Ad Ignorantiam. Argumentation, 13, 1999: 367-377.

Zuo, Yan. The Golden Silence: A Pragmatic Study on Silence in Dyadic English Conversation. Lincom Europa, Munchen, 2002. 